ISSN 0258-7122

Bangladesh J. Agril. Res. 35(2) : 267-272, June 2010

\title{
EFFECT OF UREA SUPER GRANULE ON THE PERFORMANCE OF CABBAGE IN YOUNG JAMUNA AND BRAHMAPUTRA FLOODPLAIN SOILS OF TANGAIL
}

\author{
M.J. HUSSAIN ${ }^{1}$, M.Y. ALI ${ }^{2}$, M. A. RAHMAN ${ }^{1}$ \\ M. A. QUAYYUM ${ }^{3}$ AND D. A. CHOUDURY ${ }^{4}$
}

\begin{abstract}
A number of experiments were conducted at the Farming Systems Research and Development (FSRD) site, Palima, Tangail for three consecutive years to evaluate the efficiency of USG application in comparison with prilled urea on the yield and yield attributes of cabbage (cv. Atlas-70). There were five treatments, $\mathrm{T}_{1}=\mathrm{N}_{195}$ (recommended $\mathrm{N}$ dose for HYG, used as prilled urea), $\mathrm{T}_{2}=$ $\mathrm{N}_{195}$ (recommended $\mathrm{N}$ dose for HYG, used as USG), $\mathrm{T}_{3}=\mathrm{N}_{175}$ (N 10\% reduction of recommended $\mathrm{N}$ dose as USG), $\mathrm{T}_{4}=\mathrm{N}_{155}$ (N 20\% reduction of recommended $\mathrm{N}$ dose as USG), and $\mathrm{T}_{5}=\mathrm{N}_{105}$ (Farmers' $\mathrm{N}$ dose used as prilled urea). Treatments $\mathrm{T}_{1}-\mathrm{T}_{4}$ received recommended dose of other nutrients $\left(\mathrm{P}_{56} \mathrm{~K}_{162} \mathrm{~S}_{13} \mathrm{Mo}_{0.6} \mathrm{CD}_{3 \mathrm{t}}\right)$ and $\mathrm{T}_{5}$ received $\mathrm{P}_{25} \mathrm{~K}_{90} \mathrm{~S}_{0} \mathrm{Mo}_{0} \mathrm{CD}_{51}$ Yield and yieldcontributing characters of cabbage significantly responded to the application of USG. The highest head yield (78.1 t/ha) was obtained with the recommended dose of $\mathrm{N}$ as USG, and 10\% (77.1 t/ha), and 20\% (72.0 t/ha) less than the recommended dose of $\mathrm{N}$ as USG also produced higher yield than recommended prilled urea-N. Application of USG was found more efficient than prilled urea and the treatment $\mathrm{N}_{195} \mathrm{P}_{56} \mathrm{~K}_{162} \mathrm{~S}_{13} \mathrm{Mo}_{0.6} \mathrm{CD}_{3 \mathrm{t}}$ (recommended $\mathrm{N}$ as USG for HYG) was found profitable for cabbage cultivation in terms of yield and the treatment $\mathrm{N}_{175} \mathrm{P}_{56} \mathrm{~K}_{162} \mathrm{~S}_{13} \mathrm{Mo}_{0.6} \mathrm{CD}_{3 \mathrm{t}}(10 \% \mathrm{~N}$ reduction of recommended $\mathrm{N}$ dose as USG) was found profitable in terms of economic returns.
\end{abstract}

Keywords: USG, prilled urea, cabbage.

\section{Introduction}

Cabbage (Brassica oleracea var. capitata Lin.) is one of the popular and nutritious vegetable crops in Bangladesh for being a good source of vitamin A, $\mathrm{B}$, and C, Ca and Fe (Atwal, 1976). It is cultivated all over the country with an annual production of 183 thousand metric tons (BBS, 2007). However, average yield (10.25 t/ha) of the crop in Bangladesh is low compared to that in some advanced countries of the world. The low yield of cauliflower in Bangladesh is primarily due to lack of high yielding varieties, inadequate manuring, and fertilization, especially nitrogen and improper agronomic practices.

Nutrient supply is a key factor in crop production, but global crisis of energy and high costs of fertilizer nutrients necessitate economizing their use. Nitrogen

${ }^{1}$ Scientific Officer, ${ }^{2}$ Principal Scientific Officer, ${ }^{3}$ Chief Scientific Officer, ${ }^{4}$ Senior Scientific Officer, OFRD, Bangladesh Agricultural Research Institute (BARI), Joydebpur, Gazipur1701, Bangladesh. 
is the most deficient nutrient element in Bangladesh soil and cabbage needs a large amount of $\mathrm{N}$ fertilizer. Urea Super Granule (USG) is one of the popular N fertilizers and farmers have adopted it in boro rice cultivation. It was assumed that application of USG could also be profitable in different upland vegetables and fruit crops, such as cabbage, cauliflower, brinjal, banana, etc. According to Creswell and De Datta (1980), broadcast application of urea on the surface soil causes loss upto $50 \%$ but point placement of USG in $10 \mathrm{~cm}$ depth can save $30 \%$ nitrogen as prilled urea, increase absorption rate, improve soil health and ultimately increase rice yield (Savant et al., 1991). It was reported that the grain yield of millet was the highest with BCUSG and the lowest with urea and in case of wheat, among $\mathrm{N}$ sources residual effects were in the order BCUSG> USG>BCU> urea (Sarker and Faroda, 1993). The N uptake and recovery of applied $\mathrm{N}$ were the highest in the USG + urea treatment and $\mathrm{N}$ use efficiency was highest with urea alone (Saha, 1984). In a field experiment, wheat grain yield increased with increasing residual $\mathrm{N}$ rate and was highest after deep placement of $120 \mathrm{~kg} \mathrm{~N}$ as USG (Das et al., 1994). Modified urea materials under different moisture regimes influence $\mathrm{NH}_{3}$ volatilization loss and significantly less $\mathrm{NH}_{3}-\mathrm{N}$ loss was observed for USG treatments than from surface applied urea (Muneshwar et al., 1992). However, research on USG management in cabbage is inadequate in Bangladesh. Therefore, the present study was undertaken to evaluate the efficiency of USG in comparison with prilled urea and also to determine the optimum dose of USG with respect to yield and yield attributes of cabbage.

\section{Materials and Method}

The experiment was carried out in the medium highland of AEZ-8 (Young Jamuna and Brahmaputra Floodplain) at the Farming Systems Research and Development site, Palima, Tangail of Bangladesh Agricultural Research Institute (BARI) during rabi seasons of 2000-2001, 2001- 2002 and 2002-2003. Prior to experimentation of 2000-01, the soil was analyzed for different properties. Soil is slightly acidic ( $\mathrm{pH} 5.8$ ) with medium contents of organic matter (1.72\%), very low content of total N (0.072\%), and P $(5.20 \mu \mathrm{g} / \mathrm{g})$, low k (0.lcrnol $/ \mathrm{kg}, \mathrm{S} 13$ $(\mu \mathrm{g} / \mathrm{g}), \mathrm{B}(0.91 \mu \mathrm{g} / \mathrm{g})$, and high Zn $(7.53 \mu \mathrm{g} / \mathrm{g})$. The experiment was laid out in a randomized compete block design (RCBD) having 6 dispersed replications. Five treatments were $T_{1}=N_{195}$ (recommended dose for HYG, $N$ as prilled urea), $T_{2}=$ $\mathrm{N}_{195}$ (recommended dose for HYG, $\mathrm{N}$ as USG), $\mathrm{T}_{3}=\mathrm{N}_{175}$ (N 10\% reduction of recommended $\mathrm{N}$ dose as USG), $\mathrm{T}_{4}=\mathrm{N}_{155}$ ( $\mathrm{N} 20 \%$ reduction of recommended $\mathrm{N}$ dose as USG), and $\mathrm{T}_{5}=\mathrm{N}_{105}$ (Farmers' $\mathrm{N}$ dose, $\mathrm{N}$ as prilled urea). Farmers' dose was identified by the average dose of 30 farmers' practice in that area.

Treatments $\mathrm{T}_{1}=\mathrm{T}_{4}$ received $56 \mathrm{~kg} \mathrm{P}, 162 \mathrm{~kg} \mathrm{~K}, 13 \mathrm{~kg} \mathrm{~S}, 0.6 \mathrm{~kg}$ Mo, and 3 tons of CD per ha (all recommended dose). The doses for farmer's practice $\left(\mathrm{T}_{5}\right)$ 
were $25 \mathrm{~kg} \mathrm{P}, 90 \mathrm{~kg} \mathrm{~K}, 0 \mathrm{~kg} \mathrm{~S}, 0 \mathrm{~kg}$ Mo, and 5 tons CD per ha. Moreover, a common dose of boron fertilizer was applied @ $1 \mathrm{~kg}$ B/ha for all the treatments. The unit plot size was $8 \mathrm{~m} \times 5 \mathrm{~m}$. and variety was Atlas-70. Seedlings were transplanted at a spacing of $45 \mathrm{~cm} \times 60 \mathrm{~cm}$ for plant-plant and line-line, respectively. Transplantation was done with 30-day-old seedlings in the first week of November every year. Fertilizers were calculated on the basis of soil test values (FRG, 1997). Except prilled urea and USG, all other fertilizers and 50\% MoP were applied during final land preparation. For each year, USG was applied at 10 days after transplanting (DAT), in ring method as $9-10 \mathrm{~cm}$ apart from the seedling base and at 7-8 $\mathrm{cm}$ depth in soil. Prilled urea was applied as 3 equal splits at 10 DAT, 25 DAT, and 35 DAT (head initiation stage) and covered with soil properly. Rest 50\% MoP was applied with USG and prilled urea at 10 days after transplanting.

Three irrigations were applied at 15, 25, and 40 DAT. Two weedings and mulching were done at 20 and 30 DAT. The crop was also free from pest attack. Harvesting was started in January and continued upto the end of February. Data on yield and yield contributing characters were recorded from 10 plants selected randomly for each plot and total yield was calculated by multiplying average plant yield with plant population. Data were collected and analyzed statistically using MSTAT-C package and means were separated by DMRT at 5\% level of significance.

\section{Results and Discussion}

\section{Yield attributes of cabbage}

Yield and yield contributing characters were studied and three years' pooled data are presented in Table 1 and economic analyses are presented in Table 2. Results revealed that among the characters except number of outer leaves, plant height, head diameter, head pericycle, head length, head weight with outer leaves, head weight without outer leaves and head yield showed significant differences among the treatments. Highest plant height $(22.07 \mathrm{~cm})$ was found with the recommended USG dose, which was statistically similar to USG $10 \%<$ recommended dose and the lowest plant height $(19.98 \mathrm{~cm})$ was resulted from farmers' practice. Highest head diameter $(22.91 \mathrm{~cm})$, head pericycle $(70.67 \mathrm{~cm})$ and head length $(14.89 \mathrm{~cm})$ were produced by the recommended USG, which was statistically similar to recommended prilled urea, $10 \%$ and $20 \%$ recommended USG dose but different from farmers' practice. No significant difference was observed in number of outer leaves among the treatments. 
Table 1. Effect of USG and PU on the yield contributing characters of cabbage (3 years average data).

\begin{tabular}{|c|c|c|c|c|c|c|c|}
\hline Treatments & $\begin{array}{l}\text { Plant } \\
\text { height } \\
(\mathrm{cm})\end{array}$ & $\begin{array}{c}\text { Head } \\
\text { diamerer } \\
(\mathrm{cm})\end{array}$ & $\begin{array}{c}\text { Head } \\
\text { pericycle } \\
(\mathrm{cm})\end{array}$ & $\begin{array}{l}\text { Head } \\
\text { length } \\
(\mathrm{cm})\end{array}$ & $\begin{array}{l}\text { Head wt } \\
\text { with outer } \\
\text { leaves } \\
\text { (kg) }\end{array}$ & $\begin{array}{c}\text { Head wt } \\
\text { without } \\
\text { outer } \\
\text { leaves } \\
(\mathrm{kg})\end{array}$ & $\begin{array}{l}\text { Head } \\
\text { yield } \\
\text { (t/ha) }\end{array}$ \\
\hline $\begin{array}{l}\text { Prilled urea } \\
\text { (Rec. N) }\end{array}$ & $21.00 \mathrm{~b}$ & $21.97 \mathrm{a}$ & $67.86 a$ & $14.28 \mathrm{a}$ & $2.73 b c$ & $2.08 \mathrm{bc}$ & $70.03 \mathrm{~b}$ \\
\hline USG (Rec.N) & $22.07 a$ & $22.91 \mathrm{a}$ & $70.67 a$ & $14.89 a$ & $3.00 \mathrm{a}$ & $2.35 \mathrm{a}$ & $78.07 \mathrm{a}$ \\
\hline $\begin{array}{l}\text { USG } \\
(10 \%<\text { Rec.. N) }\end{array}$ & $21.82 \mathrm{a}$ & $22.78 \mathrm{a}$ & $69.81 \mathrm{a}$ & $14.77 \mathrm{a}$ & $2.97 a b$ & 2.28ab & 77.10a \\
\hline $\begin{array}{l}\text { USG } \\
(20 \%<\text { Rec. } N)\end{array}$ & $21.17 b$ & $22.20 \mathrm{a}$ & $67.96 a$ & $14.49 \mathrm{a}$ & $2.79 \mathrm{ab}$ & $2.13 b$ & $72.03 \mathrm{~b}$ \\
\hline Farmers' dose & $19.98 \mathrm{c}$ & $20.61 b$ & $64.85 b$ & $13.49 \mathrm{~b}$ & $2.52 \mathrm{c}$ & $1.89 \mathrm{c}$ & $61.07 \mathrm{c}$ \\
\hline LSD (5\%) & 0.60 & 1.35 & 2.91 & 0.89 & 0.24 & 0.20 & 3.97 \\
\hline CV (\%) & 1.49 & 3.25 & 2.26 & 3.33 & 4.55 & 4.82 & 2.94 \\
\hline
\end{tabular}

Means followed by common letters are not significantly different at $5 \%$ level of probability.

Head weight with outer leaves and head weight without outer leaves also differed significantly among the treatments. The highest head weight with outer leaves $(3.00 \mathrm{~kg})$ was obtained from the recommended USG, which was statistically identical with $10 \%$ and $20 \%$ reduction of the N dose (USG), but it was significantly higher than recommended prilled urea and farmers' practice. The highest head weight without outer leaves $(2.35 \mathrm{~kg})$ was also obtained from recommended USG followed by $10 \%<$ than recommended USG dose $(2.28 \mathrm{~kg})$, but different from all other treatments. Farmers' dose produced the lowest head weight without outer leaves $(1.89 \mathrm{~kg})$. It was due to minimized ammonia volatilization loss and less $\mathrm{NH}_{3}-\mathrm{N}$ loss for USG treatments as reported by Muneshwar et al. (1992).

\section{Head yield of cabbage}

Head yield of cabbage was significantly influenced by the application of different doses of prilled urea and USG (Table 1). It appeared that in general yield of cabbage was increased by the application of USG in comparison with prilled urea and the highest yield (78.07 t/ha) was obtained from recommended $\mathrm{N}$ dose as USG, which was statistically identical with the treatment $10 \%<$ recommended USG (77.10 t/ha), but it was different from recommended prilled urea and $20 \%<$ recommended USG. This might be due to the higher use efficiency of nitrogen by the slow releasing property of USG and its deep placement. This result was 
supported by the findings of Setty et al. (1987) where USG produced the highest grain yield in rice. Das et al. (1994) reported that wheat grain yield increased with increasing residual nitrogen rate and was highest after deep placement of $120 \mathrm{~kg} \mathrm{~N}$ as USG. The soil test value showed that the experimental field was deficit in $\mathrm{N}, \mathrm{P}, \mathrm{K}$, and $\mathrm{S}$. So, the application of these fertilizers including $\mathrm{P}$ probably helped maintaining the soil fertility and showed favourable response to the required nutrients. Muneshwar et al. (1992) reported that modified urea materials under different moisture regimes influence ammonia volatilization loss and significantly less $\mathrm{NH}_{3}-\mathrm{N}$ loss was observed for USG treatments than from surface applied urea. So, the application of $10 \%$ less $\mathrm{N}$ fertilizer as USG also performed better than the recommended prilled urea due to higher uptake and recovery rate of $\mathrm{N}$, and minimum volatilization loss of $\mathrm{N}$ fertilizer. Similar result was observed by Saha (1984) where N uptake and recovery of applied $\mathrm{N}$ were the highest in the USG + urea treatment and $\mathrm{N}$ use efficiency was highest with urea alone. Farmers' practice resulted in the lowest yield (61.0 t/ha) due to unbalanced fertilizer use.

\section{Cost and return analysis}

Economic evaluation of different treatments has been shown in Table 2. Though higher cost was involved in USG practice and 10\% less USG than recommended dose in comparison with prilled urea, the highest gross margin (Tk.117588) was obtained from the $\mathrm{N}$ recommended dose of $\mathrm{N}$ as USG among the treatments. Even 10\% and 20\%<rec. USG showed higher gross return (Tk.190342 and Tk. 189286) and gross margin (Tk. 116847 and Tk. 105904) than prilled urea and farmers' dose. The highest and similar benefit cost ratio (BCR) of 2.61 was achieved from USG use as a source of N and USG $10 \%<$ recommended dose. But the lowest BCR was resulted from prilled urea treatment due to higher fertilizer cost and lower yield performance. MBCR was also higher in USG treated plot and the highest MBCR (12.83) was obtained from USG 10\% < rec. dose followed by recommended USG dose. The present study indicates that USG, as a source of $\mathrm{N}$ is more efficient than that of prilled urea. Therefore, 175 to $195 \mathrm{~kg} \mathrm{~N}$ as USG i.e., $10-12$ balls of USG (0.90 g/ball) per plant, placing 9-10 $\mathrm{cm}$ apart from plant base and 7-8 $\mathrm{cm}$ depth in soil as ring method at 10 DAT along with other fertilizers as $\mathrm{N}_{175} \mathrm{P}_{56} \mathrm{~K}_{162} \mathrm{~S}_{13} \mathrm{Mo}_{0.6} \mathrm{CD}_{3 \mathrm{t}}$ (N 10\%<Recommended dose as USG) to $\mathrm{N}_{195} \mathrm{P}_{56} \mathrm{~K}_{162} \mathrm{~S}_{13} \mathrm{Mo}_{0.6} \mathrm{CD}_{3 \mathrm{t}}$ (Recommended dose for HYG, $\mathrm{N}$ as USG) was found the most suitable dose for obtaining the maximum yield and economic benefit in cabbage cultivation in the Young Jamuna and Brahmaputra Floodplane soils of Tangail in Bangladesh. 
Table 2. Cost and return analysis of the treatments effect on cabbage production (Average of 3 years).

\begin{tabular}{|c|c|c|c|c|c|}
\hline Treatments & $\begin{array}{l}\text { Gross return } \\
\text { (Tk./ha) }\end{array}$ & $\begin{array}{c}\text { TVC } \\
\text { (Tk./ha) }\end{array}$ & $\begin{array}{c}\text { Gross } \\
\text { margin } \\
\text { (Tk./ha) }\end{array}$ & BCR & $\begin{array}{l}\text { MBCR over } \\
\text { control }\end{array}$ \\
\hline $\begin{array}{l}\text { Prilled urea (Rec. } \\
\text { N) }\end{array}$ & 171693 & 72754 & 98939 & 1.74 & 5.7 \\
\hline USG(Ree.N) & 190342 & 72754 & 117588 & 2.61 & 11.8 \\
\hline USG(10\%<Rec.N) & 189286 & 72439 & 116847 & 2.61 & 12.8 \\
\hline USG(20\%<Rec.N) & 178085 & 72181 & 105904 & 2.47 & 9.6 \\
\hline Farmers’ dose & 153889 & 69679 & 84210 & 2.20 & - \\
\hline \multicolumn{2}{|c|}{ Price of inputs: Tk./kg } & \multicolumn{3}{|c|}{ Price of output: Tk./kg } & \\
\hline Urea & $: 5.70$ & Cabba & e $: 2.50$ & & \\
\hline USG & $: 6.00$ & & & & \\
\hline TSP & $: 14.00$ & & & & \\
\hline MoP & : 9.00 & & & & \\
\hline Gypsum & $: 4.00$ & & & & \\
\hline Zinc sulphate & : 35.00 & & & & \\
\hline
\end{tabular}

\section{Acknowledgement}

The authors are grateful to SFFP-DANIDA for financial support.

\section{References}

Atwal, A. S. 1976. Agricultural pest of India and South Asia. Kalyani Publisher, Luddhian, $P-529$.

FRG. 1997. Fertilizer Recommendation Guide. Bangladesh Agricultural Research Council, Soils Pub. No. 41.

BBS. 2007. Statistical Yearbook of Bangladesh. Bangladesh Bureau of Statistics, Ministry of Planning, Governoment of the People's Republic of Bangladesh: 139.

Crasswell, E. T. and S. K. De Datta, 1980. Recent development in research on nitrogen fertilizers for rice. International Rice Research Institute Res. Paper. Serries No. 49: $1-11$.

Das and T. A. Sing, 1994. Residual effect of urea super granules application in rice (Oriza sativa) wheat (Triticum aestivum) cropping system. Indian J Agron. 39(4): 604-605.

Muneshwar S, P. N. Takkar, Vi Ben, M. R Chaudhary, P. S. Sidhu, N. S. Pashricha and M. S. Bajwa. 1992. Proceedings of International Symposium on Nutrient Management for Sustained Productivity. 2:7-8.

Sarker, A and A. S Faroda, 1993. Modified from if urea pearl millet-wheat sequence under subtropical conditions. Tropical Agric, 70(3): 1 79-281.

Savant N. K., S. S. Dhane and S. Talashilkar, 1991. Fertilizer News. International Fertilizer Development Center, Muscle Sholas, Alabama and 1.S.A. 36(3): 19-25. 